Religare, ISSN: 19826605, v.14, n.2, dezembro de 2017, p. 311-342.

\title{
O perigo das águas: aspectos do feminino terrivel em um conto de Galeano
}

The danger of waters: aspects of the terrible feminine in a tale of Galeano

\author{
Joyce Conceição Gimenes Romero ${ }^{1}$ \\ Maria Dolores Aybar Ramirez ${ }^{2}$
}

\section{Resumo}

O presente trabalho propõe uma breve reflexão acerca da configuração da personagem fantástica feminina no conto "Historia del lagarto que tenía la costumbre de cenar a sus mujeres" (1993), de Eduardo Galeano. Tendo em vista a perspectiva dos estudos mitocríticos que contemplam o aspecto ancestral do feminino maléfico, observa-se o modo como se produzem as manifestações da personagem-feiticeira vinculada ao feminino terrível e às águas na narrativa. Analisa-se, assim, a representação simbólica dessa mulher mágica e misteriosa que constrói a figura arquetípica de mulher sedutora e atraente, mas causadora de danos, perigosa e, por vezes, fatal. Desse modo, consideraremos a composição estética do conto que compõe nosso corpus enfocando a contribuição do mito como importante referencial para a elaboração do arquétipo feminino da Mãe Terrível, embasando nossa análise, principalmente, no diálogo interdisciplinar entre o mito, a literatura e os estudos culturais de gênero.

Palavras-chave: mulher-sereia; arquétipo; feminilidade maléfica; literatura fantástica; Eduardo Galeano.

\section{Abstract}

The present work proposes a brief reflection on the configuration of the fantastic female character in the tale "Historia del lagarto que tenía la costumbre de cenar a sus mujeres" (1993) by Eduardo Galeano. Considering the perspective of the mythical criticism studies that contemplate the ancestral aspect of the maleficent feminine, one observes the way in which the manifestations of the sorceress character

\footnotetext{
${ }^{1}$ Mestra em Estudos Literários pela Faculdade de Ciências e Letras de Araraquara - UNESP e-mail: anjoycegimenes@hotmail.com

2 Doutora em Estudos Literários pela Faculdade de Ciências e Letras de Araraquara - UNESP

Docente da Faculdade de Ciências e Letras de Araraquara- UNESP
} 
Religare, ISSN: 19826605, v.14, n.2, dezembro de 2017, p. 311-342.

linked to the terrible feminine and to the waters in the narrative. The symbolic representation of this magical and mysterious woman is thus analyzed, constructing the archetypal figure of a seductive and attractive woman, but causing damage, being dangerous and sometimes fatal. In this way, we will consider the aesthetic composition of the tale that compose our corpus focusing on the contribution of the myth as an important reference for the construction of the feminine archetype of the Terrible Mother, supporting our analysis mainly in mythological, literary and gender studies.

Keywords: mermaid-woman; archetype; evil femininity; fantastic literature; Eduardo Galeano.

Quando consideramos a figura da feiticeira desde os primórdios da literatura ocidental, uma conjuntura específica de relações chama a nossa atenção: em primeiro lugar, a associação primordial entre a figura da mulher perigosa bruxa, feiticeira, divindade ou mulher-monstro - e o elemento água, em suas mais inúmeras formas e representações. Ademais, evidencia-se também a relação entre esse mesmo arquétipo feminino e questões ligadas à sexualidade e à alimentação. Se remontamos a Homero, ponto de partida do cânone literário no Ocidente, os elementos mencionados são facilmente identificáveis em uma análise sucinta da Odisseia. Na saga do retorno de Ulisses, apresentam-se várias personagens que podem ser compreendidas de acordo com a representação de um feminino ameaçador ou maléfico. Cabe citar a sedutora ninfa Calipso que, assim, como a emblemática feiticeira Circe, habita uma ilha, terra instável inteiramente rodeada pelas águas. Habitantes de uma ilha também o são as Sirenas, cujo poder de sedução e destruição tem sido, amiúde, representado em inúmeras manifestações literárias e artísticas ao longo da história. Não podemos deixar de mencionar, tampouco, Cila e Caríbdis, criaturas femininas cuja monstruosidade propõe uma feminilidade coalhada de ameaças e perigos. De uma ou outra maneira, todas elas representam empecilhos, tentações e riscos para o engenhoso Odisseu em seu intuito de regresso à Ítaca.

No entanto, a dinâmica da associação da personagem feminina com a ameaça e as águas não se restringe às fontes ou tradições literárias europeias. Ela 
Religare, ISSN: 19826605, v.14, n.2, dezembro de 2017, p. 311-342.

resiste e se expande e pode ser abundantemente encontrada nas narrativas tradicionais de origem ameríndia ou nas que nasceram justamente do embate dialético de diferentes repertórios étnicos e culturais delineados ao longo do processo de colonização da América. A sobrevivência desse repertório ao longo do espaço e do tempo permite identificar narrativas muito distantes com surpreendentes correspondências no que se refere à construção do feminino interligado à magia, ao poder maléfico da sedução-destruição, à sexualidade, à alimentação e ao elemento água.

Partindo dessa constatação, selecionamos e analisamos o conto "Historia del lagarto que tenía la costumbre de cenar a sus mujeres" (1993), de Eduardo Galeano, que apresenta a feminilidade maléfica ligada às águas profundas em um tempo mítico que se ergue para além e para aquém da lógica do tempo histórico. Galeano, o conhecido escritor e jornalista uruguaio, dispensa apresentações, porém, a título de lembrete, cabe mencionar aqui que sua obra trespassa a literatura e tenciona o diálogo com a política e a história, mas também com o jornalismo. Efetivamente, sua primeira escrita, logo na década de 60, iniciou-se no universo do jornal, atuando como editor em alguns importantes jornais como Marcha e Época. Como escritor, ganha notoriedade a partir de 1971, com o lançamento de sua mais conhecida obra, Las venas abiertas de América Latina. Dado esse trânsito constante entre política, história e literatura - fato que demonstra seu intenso conhecimento de diversas propostas ideológicas e estéticas - o autor imprime em sua obra ficcional a denúncia própria de um jornalismo engajado e crítico sem abandonar questões estéticas inerentes ao discurso literário. Desse modo, a estudiosa chilena Ana Pizarro (1995) conclui que, em Galeano, esses dois discursos se fundem para criar uma nova forma narrativa denominada literatura de testemunho.

No entanto, a obra de Galeano não se configura apenas pelo elemento político no sentido mais estrito. $\mathrm{O}$ político não dispensa em sua obra nem o poético nem o mítico. $\mathrm{O}$ exercício poético permite temáticas míticas desenvolvidas por vezes na forma de relatos surpreendentemente curtos, 
Religare, ISSN: 19826605, v.14, n.2, dezembro de 2017, p. 311-342.

espalhados por muitas de suas obras que, por sua vez, recuperam elementos críticos sobre a condição da mulher no seio do patriarcado. Em microcontos algumas vezes articulados em não mais que dez linhas - o autor focaliza uma história que ilustra a realidade social mais abrangente. Suas histórias, ora oriundas de uma tradição oral hispano-americana reelaborada, ora procedentes de um evento empírico que cria a imagem de um narrador-testemunha, rompem os limites entre o texto que documenta um suposto real e a mais pura ficção e oferecem uma leitura de contos curtos tradicionais, armados sobre bases míticas. Isso, porém, sem abandonar pungentes críticas de cunho ideológico que, no caso que concerne à nossa análise, tencionam mapear e minar as bases do patriarcado e denunciar a condição da mulher nesse sistema social.

Quando abordamos essas questões no conto "Historia del lagarto que tenía la costumbre de cenar a sus mujeres", lançado no livro Las palabras andantes (1993) e republicado em Mujeres (1995), percebemos nitidamente esses diálogos complexos entre mito, história e ficção assim como a configuração de um discurso poético engajado. Mujeres é um compêndio de microcontos que apresenta releituras míticas universalmente ligadas à questão da mulher, algumas de cunho mágico, cuja temática desenvolve a histórica discriminação de gênero. Galeano, notoriamente reconhecido por seu engajamento social, não pode deixar de transparecer nessa obra sua delicada percepção de mundo e, através do rico e profícuo universo da literatura fantástica, recompor e questionar velhos paradigmas e arquétipos pertencentes à literatura e ao imaginário a partir de uma perspectiva clara de defesa da mulher e de sua voz silenciada pela história.

Nesse sentido, em "Historia del lagarto que tenía la costumbre de cenar a sus mujeres", narra-se a história de um homem poderoso, dono do imenso território de Lucanamarca, e de sua mulher que, ao fim de muita espera, concebem finalmente um herdeiro. A criança, porém, nasce com cara de gente e corpo de lagarto. Apesar dessa hibridez, Dulcidio, o primogênito, cresce sem maiores complicações. Aos dezoito anos, porém, o rapaz "pede mulher" e, após uma pomposa celebração, devora a esposa na noite nupcial. Esse fato repete-se em 
Religare, ISSN: 19826605, v.14, n.2, dezembro de 2017, p. 311-342.

sucessivos casamentos e "banquetes nupciais" com a aquiescência e ajuda dos dedicados pais do noivo até que o homem-lagarto conhece uma mulher misteriosa pela qual se apaixona. Em uma inversão de papéis, a mágica mulher devora seu marido no mesmo leito de núpcias em que este devorara suas predecessoras.

A personagem feminina dessa narrativa é notadamente obscura. Jamais nomeada, essa mágica mulher condensa em si características que nos permitem identificá-la como a manifestação da mulher fatal e da bruxa vinculada ao feminino terrível que se perfaz frequentemente na literatura Ocidental, principalmente nas obras que apresentam caráter mágico, maravilhoso ou fantástico. Do encantamento de Dulcidio pela enigmática personagem ao pronto casamento e à epifania catártica da inversão final, quando o devorador brutal, já transformado no enamorado noivo, é engolido brandamente pela mulher alvo de seus desejos, verifica-se a presença de elementos estruturais de origem mítica que se apresentam literariamente, bem como a configuração de imagens arquetípicas acerca do feminino.

Dulcidio constrói-se como importante contraponto dessa feminilidade e é ele que nos auxilia na análise da hermética personagem feminina porquanto se apresenta como seu oponente. Nesse embate de forças narrativas, progressivamente, e graças à sedução da feiticeira, o protagonismo do herói sucumbe perante a crescente presença da heroína. Esse protagonismo, como sua vida, lhe é subtraído ardilosamente por uma mulher que inverte a lógica primária do relato ao transformar o predador em vítima.

Conforme mencionamos, Dulcidio é o herdeiro de uma grande extensão territorial chamada Lucanamarca. Constatamos assim, a eleição de um espaço real para o desenrolar da sequência narrativa. O distrito de Santiago de Lucanamarca, que se localiza no departamento de Ayacucho no Peru, representado na obra, confere verossimilhança ao relato. A precisão espacial, bem como as duas descrições desse território encontradas no texto, atua no conto transmitindo uma impressão de poder do protagonista e parece reforçar o caráter 
Religare, ISSN: 19826605, v.14, n.2, dezembro de 2017, p. 311-342.

dominador do patriarcado, representado primeiro pelo progenitor de Dulcidio; depois, pelo próprio Dulcidio que não possui apenas territórios, mas o próprio povo local. O narrador heterodiegético, aquele que conta uma história da qual não participa, introduz o leitor ao enredo com a seguinte descrição espacial:

Todo le pertenecía: el pueblo de Lunamarca y lo de más acá y lo de más allá, las bestias señaladas y las cimarronas, las gentes mansas y las alzadas, todo: lo medido y lo baldío, lo seco y lo mojado, lo que tenía memoria y lo que tenía olvido. (GALEANO, 1995, p. 9).

As marcas "lo de más acá y ló de más allá", mais que indeterminar suas posses territoriais, denotam-nas como não passíveis de mensuração. A enumeração em pares de adjetivos revela que os elementos utilizados nessa descrição são símbolos de poder em um território rural: terras, animais e pessoas, tudo lhe pertencia. Verifica-se o mesmo empenho na demonstração de poder através da descrição paisagística na fala de Dulcidio logo após encontrar a personagem feminina pela segunda vez na beira do rio:

- Hasta donde llegan los ojos, hasta donde llegan los pies. Todo dueño soy. [...] El heredero insiste. Las ovejitas y los indios están a su mandar, Él es el amo de todas esas leguas de tierra y agua y aire, y también del pedazo de arena donde ella está sentada. (GALEANO, 1995, p. 9).

Resulta imprescindível para Dulcidio que sua figura seja diretamente relacionada ao seu status social pela personagem feminina do conto. Nesse trecho, em um discurso direto realizado por Dulcidio, esse desejo é manifesto, introduzido pela seguinte frase: "Dulcidio pone las cosas en su lugar. Alza una pata uñuda y la pasea sobre el horizonte de montañas azules". (GALEANO, 1995, p. 11).

No entanto, após a apresentação de Dulcidio, e em meio à sua busca predatória por novas noivas, vemos surgir uma misteriosa personagem feminina. A caracterização dessa figura é feita em uma distinta configuração espacial: na beira do rio e oculta pela vegetação local. Averiguamos essa oposição no conto objeto de nossa atenção: a personagem de Dulcidio, que é enquadrada pelo 
Religare, ISSN: 19826605, v.14, n.2, dezembro de 2017, p. 311-342.

espaço social e econômico concernente a um herdeiro de tão vasto território, contrasta com essa personagem feminina que tem como espaço próprio uma paisagem natural, o que, a priori, não nos parece destituído de significação.

Sentada na areia, essa personagem é retratada em sua primeira aparição como estranha àquele lugar, "Esta mujer no parece de la sierra, ni de la selva, ni de la costa". (GALEANO, 1995, p. 10). No seguinte excerto, a mesma noção de elemento estrangeiro é evocada:

Toda la servidumbre se lanza a buscarla. Los perseguidores revuelven cielo y tierra; pero ni siquiera se sabe el nombre de la evaporada, y nadie ha visto jamás a ninguna mujer de anteojos en estos valles, ni más allá. (GALEANO, 1995, p. 13).

Ambas as passagens, paralelamente aos seus desaparecimentos repentinos e sua proximidade com o rio - signo de instabilidade, transitoriedade, fluidez e movimento - conotam inicialmente a possibilidade de que ela seja uma estrangeira. Esses indícios, no entanto, são contestados imediatamente na história: "Sentada en la arenita, los pies guardados bajo las muchas polleras de colores, ella está muy estando, desde siempre estando; y así mira al intruso ése que se lagartea al sol. (GALEANO, 1995, p. 11).

Caracterizada com o peculiar traje feminino peruano ("muchas polleras de colores"), vestimentas hoje reivindicadas como tipicamente incaicas ${ }^{3}$ e regionais, porém que na verdade marcam a imposição cultural do colonizador espanhol ${ }^{4}, \mathrm{e}$ estando desde sempre ali, desde o tempo mítico do eterno, inerente ao ancestral, a personagem obtém pela enunciação do narrador a legitimação como nativa de Lucanamarca. Deduz-se, através da caracterização da personagem nesse fragmento, que sua existência nesse lugar não só precede a de Dulcidio, mas que

\footnotetext{
${ }^{3}$ A civilização inca habitou a localidade representada na obra no período pré-colombiano; nessa região ainda moram muitos de seus descendentes.

${ }^{4}$ De acordo com Galeano (2015, p. 75): “Os turistas adoram fotografar os indígenas do altiplano vestidos com suas roupas típicas. Ignoram, por certo, que a atual vestimenta indígena foi imposta por Carlos III em fins do século XVIII. Os trajes femininos que os espanhóis obrigaram as índias a usar eram cópias dos vestidos regionais das lavradoras estremenhas, andaluzas e bascas, e outro tanto ocorre com os penteados das índias, repartido ao meio, imposto pelo vice-rei Toledo.".
} 
Religare, ISSN: 19826605, v.14, n.2, dezembro de 2017, p. 311-342.

tal antagonismo culmina na identificação dele como o verdadeiro intruso.

Dulcidio, sob essa perspectiva, é o colonizador que, como opressor, apropria-se do espaço territorial e impõe seu poder mediante a violência, sem encontrar oposição ou resistência por parte da população nativa. Ele se contrapõe à personagem da misteriosa mulher cuja espacialidade situa-se ao ar livre, em contato direto com a terra, a água e toda a natureza e que, apesar de colonizada, mantém seu vínculo com tempos incomensuravelmente anteriores. Verificamos, assim, a aproximação de mulher e natureza que se evidencia no delineamento dessa personagem feminina através de aspectos espaciais pontuados na obra, significativamente relevantes na composição dessa personagem. A narrativa de Galeano propõe uma divisão dicotômica segundo a qual reserva-se, para o imaginário feminino, características da natureza, de cunho emocional, e traços que seriam intrínsecos ao gênero, como a malícia e o mistério. No âmbito do masculino, estariam os elementos que se relacionam à racionalidade, à objetividade e ao controle emocional.

Assim, enquanto o espaço de Dulcidio é a alcova, onde devora as suas esposas, o espaço de nossa nebulosa mulher é a dimensão externa, desconhecida e, portanto, temível, o espaço aberto e natural. A ambientação de Dulcidio nos é retratada inicialmente como um leito nupcial onde, após seu primeiro casamento, encontra-se já viúvo, dormindo rodeado pelos ossos da defunta (GALEANO, 1995). "Historia del lagarto que tenía la costumbre de cenar a sus mujeres" transcende, pois, a noção de espaço como mero pano de fundo de ações, admitindo a transmutação do ambiente pela impressão da personagem. Assim, após os dois encontros das personagens centrais e a conversão de Dulcidio em um apaixonado romântico, esse local se transforma em um lugar de lamento e isolamento. Já a mítica personagem parece fundir-se com a natureza, com o espaço e com o tempo: "Sentada en la arenita, los pies guardados bajo las muchas polleras de colores, ella está muy estando..." (GALEANO, 1995, p. 11).

De fato, o eterno feminino e o sentimento de natureza caminham lado a lado na literatura (DURAND, 1997), sendo que a natureza, em todas as suas 
Religare, ISSN: 19826605, v.14, n.2, dezembro de 2017, p. 311-342.

manifestações, vive de impulsos. São da ordem da natureza os critérios de universalidade e espontaneidade, aquilo que está separado da cultura e é por esta particularizado, percebido como domínio da relatividade e do constrangimento. Segundo Lévi-Strauss (1996), para a elaboração dessa constelação de imagens é necessário um acordo entre natureza e cultura, entre as pulsões reflexas do sujeito e o seu meio, que enraíza de maneira tão imperativa as grandes imagens na representação e as carrega de uma felicidade suficiente para perpetuá-las.

Assim, nota-se que, a personagem feminina, por vezes, não atende às expectativas do homem lagarto, desaparecendo e reaparecendo segundo sua intenção e vontade. Além disso, suas reações e respostas também não se realizam conforme o que é esperado por Dulcidio, deste modo, ela não se admira com a constante exibição de sua riqueza ou de sua inteligência. Essa imprevisibilidade, que caracterizaria também os fenômenos naturais, tipifica essa personagem e aproxima sua configuração ao espaço que lhe é designado na narrativa. Dessa ambiguidade e mistério, do poder sobre o herói e de sua conexão "fusional" com seu entorno surgem os primeiros indícios de sua verdadeira natureza maléfica.

Porém, o aspecto que mais e melhor a caracteriza e aproxima do arquétipo mítico da feiticeira é sua relação com o tempo cíclico primitivo ou com o tempo mítico5: “...ella está estando, desde siempre estando..." (GALEANO, 1995, p. 11). Essa particularização por si só, já concede indicativos de uma sobrenaturalidade que distancia a personagem das condições limitadoras da humanidade. Outrossim, a personagem feminina perde sua individualidade na ausência de designação nominal. Tratada apenas pelo artigo feminino "ella", a inominada figura parece condensar em sua composição todas as entidades femininas vingadoras. Deste modo, a sugerida indeterminação do sujeito não parece, neste caso, suficiente para fragmentá-lo, pois esse preserva sua identidade devido à sua conexão com o espaço, sua origem e sua condição feminina. Tamanha é sua relevância que essa

5“O tempo sagrado se apresenta sob o aspecto paradoxal de um tempo circular, reversível e recuperável, espécie de eterno presente mítico que o homem reintegra periodicamente pela linguagem dos ritos." (ELIADE, 2001, p.64) 
Religare, ISSN: 19826605, v.14, n.2, dezembro de 2017, p. 311-342.

emblemática figura condensa em si o dínamo de toda a transformação do desfecho e, ao longo do relato, vai progressivamente se sobressaindo, personificando o próprio fenômeno meta-empírico ${ }^{6}$ no final da narrativa. É, portanto, por meio dessa personagem que se delineia a construção do arquétipo feminino sob o aspecto do "feminino terrível", objeto que nossa análise mitocrítica propõe-se a abordar.

Gilbert Durand (1997) propõe uma estruturação do imaginário por meio da categorização das significações inerentes às imagens que são identificáveis em culturas diversas. Ele busca, dessa forma, desnudar as bases míticas do pensamento humano por meio de uma lógica constelacional, distinguindo duas classificações: o regime diurno e o regime noturno das imagens. No entanto, para o autor, essas categorias não constituem "agrupamentos rígidos de formas imutáveis" (DURAND, 1997, p. 64), há, antes, uma tendência dialógica de organização dessas estruturas.

Assim, verificamos, no regime diurno (em que predominam ideias relacionadas à ascensão, heroísmo, razão e a preocupação com a conquista e dominação), uma configuração antitética, que se baseia no embate desse regime contra os símbolos que remetem à morte e à passagem do tempo. O regime noturno, por sua vez, organiza-se em torno de imagens que se referem à descida, ao engolimento, às trevas e ao ciclos e, diferentemente do diurno, estabelece uma dinâmica de fusão e harmonização das forças antitéticas do imaginário.

A própria composição da personagem de Dulcidio já nos remete a uma construção variegada no que se refere aos regimes de Durand (1997). Nesse sentido, o anômalo corpo da personagem é formado da hibridez entre homem e réptil e, ainda que esse animal possa estar presente na obra do autor como pertencente ao regime diurno das imagens - especificamente ao aspecto negativo dos símbolos teriomórficos - ele também se vincula ao regime noturno pelo seu aspecto temporal e por estar relacionado ao rito cíclico de casamento e devoração.

\footnotetext{
${ }^{6}$ Nomenclatura utilizada por Filipe Furtado (1980) para designar os fenômenos inexplicáveis que perturbam o equilíbrio das ações na narrativa fantástica.
} 
Religare, ISSN: 19826605, v.14, n.2, dezembro de 2017, p. 311-342.

Assim: “O simbolismo da transformação temporal é ele próprio sobredeterminado no réptil. Este último é ao mesmo tempo animal de muda, que muda de pele permanecendo ele mesmo, e liga-se por isso aos diferentes símbolos teriomórficos do Bestiário lunar (...)" (Id. Ibid., p. 316).

Podemos ainda associar também a constituição física monstruosa da personagem com outro símbolo do regime noturno descrito por Durand, o dragão:

O Dragão parece resumir simbolicamente todos os aspectos do regime noturno da imagem (...). Nada é mais comum que a ligação entre o arquétipo sáurio e os símbolos vampirescos ou devoradores. Todos os relatos lendários descrevem com horror as exigências alimentares do Dragão: em Bordéus monstro devorava uma virgem por dia, tal como em Tarascon e Poitiers. Essa ferocidade aquática e devorante vai popularizar-se em todos os Bestiários medievais (...) (1997, p. 97)

É interessante notar que, embora o corpo de Dulcidio seja de réptil, sua cabeça permanece humana. Essa, de acordo com Durand (1997), é compreendida tradicionalmente como "centro e princípio de vida, de força física e psíquica, e também receptáculo do espírito" (1997, p. 141). A cabeça também se relaciona ao regime diurno pela presença da boca devoradora, símbolo de sua ferocidade cruel: "O animal é assim, de fato, o que agita, o que foge e que não podemos apanhar, mas é também o que devora, o que rói." (DURAND, 1997, p. 90).

Dialogicamente, se por um lado verificamos no "costume" de Dulcidio uma representação da animalidade devoradora que se vincula ao regime diurno das imagens, por outro, sua prática grotesca se enquadra perfeitamente na dominante digestiva, no regime noturno, delimitada pela obra de Durand (1997). No seguinte trecho, o mitólogo, partindo de um pressuposto de Bachelard, desenvolve e elucida:

A gulodice é uma aplicação do princípio de identidade. Melhor: o princípio de identidade, de perpetuação das virtudes substanciais, recebe o seu primeiro impulso da meditação da assimilação alimentar, assimilação sobredeterminada pelo caráter secreto, íntimo de uma operação que se efetua integralmente nas trevas viscerais. (Id. Ibid., p. 257). 
Religare, ISSN: 19826605, v.14, n.2, dezembro de 2017, p. 311-342.

Para Durand (1997), o gesto da descida digestiva e todo o esquema de engolição, que compreende desde a manducação até a devoração final, remete às fantasias da profundidade e aos arquétipos de intimidade e interiorização e subtendem, portanto, o simbolismo noturno das imagens. Assim, ainda dentro desse regime, encontra-se o que, para Durand, seria o elo entre sexualidade e digestão. Muitos outros estudiosos do mito conservam essa ligação entre a temática digestiva e a sexualidade: "Desde Freud sabemos explicitamente que a gulodice se encontra ligada à sexualidade, o oral sendo o emblema repressivo do sexual". (Id. Ibid., p. 117).

Sabe-se que o tabu sexual utiliza com frequência, como meio de transmissão, o tabu alimentar como forma de linguagem. Essa aproximação se apura e se especifica na conexão entre esquemas digestivos de devoração e feminino: “O útero [...] torna-se a mandíbula devoradora” (NEUMANN, 2003, p. 70) e desperta imagens do apodrecimento e da decomposição. Essa seria a origem do mito da vagina dentada. Para Neumann (2003), esse mito expressaria a ameaça que o coito representa para os homens que, apesar de entrarem triunfantemente com a manifestação de sua ativa masculinidade, saem sempre diminuídos e simbolicamente derrotados. Esse mesmo mito é ainda retomado por Galeano (1995) em “El miedo", conto que também compõe Mujeres (1995).

Por outro lado, a questão do canibalismo, especificamente, engendra imagens distintas dentro da obra. Maria Cândida Ferreira de Almeida, em sua obra Tornar-se outro - O topos canibal na literatura brasileira (2002), elabora um interessante panorama da temática canibal na literatura. A autora considera que a presença desse tópico pode ser tomada como uma releitura da cosmologia ameríndia e define a distinção conceitual entre dois tipos de canibalismo. O primeiro, conhecido como antropofagia, é considerado o ato de devoração ligado a um ritual e, portanto, submetido a certas leis morais. Desse modo, ele se constitui como um ato socializado e justificado dentro de um determinado grupo. O segundo, conhecido como canibalismo por contingência ou canibalismo 
Religare, ISSN: 19826605, v.14, n.2, dezembro de 2017, p. 311-342.

nutritivo, estaria ligado ao ato isolado de alimentar-se da carne humana, sendo que esse minimizaria o valor simbólico do ato canibal e estaria ligado ao primitivismo e à transgressão.

Esse tema alimentar parece-nos também isotópico de todas as alusões bucais que o conjunto mítico da "Mãe das águas" comporta. Esses símbolos são aspectos negativos extremos da fatalidade que provém da sexualidade feminina e que é personificada em Circe, Calipso ou Nausícaa e, no corpus de nosso trabalho, encontra correspondência na inominada mulher. Remete-nos ainda à figura da deusa Kali, que é representada tragando gulosamente as entranhas de sua vítima ou ainda antropófaga, bebendo sangue humano num crânio. Sua voracidade canibal se materializa na representação de uma dentição abundante e animalizada, que imita as presas hediondas dos predadores. Outra possível relação mítica se dá com os demônios semíticos Benoth Ya'anah que, filhas da voracidade para os árabes, foram incluídas no livro sagrado dos cristãos e são representadas, em sua natureza híbrida, ora como sereias, ora como avestruzes. (MIQUÉIAS, 1:8).

A personagem feminina do conto de Galeano surge no início da narrativa como uma mulher que lê à beira do rio e é através de seu livro que somos informados a respeito das circunstâncias da concepção de Dulcidio e de seu nascimento como ser híbrido "El niño tenía cara de gente y cuerpo de lagarto" (GALEANO, 1995, p. 9). Em poucos parágrafos, tomamos conhecimento de toda a sua saga, incluindo seus consecutivos casamentos e deglutições de suas esposas até o encontro com essa mulher misteriosa que parece conhecer toda a história de Dulcidio e todas as histórias. Trata-se, mais uma vez, de uma mulher excepcional, que utiliza óculos, fato nunca visto antes pelo protagonista ou pelos habitantes de Lucanamarca, que se surpreendem perante o evento. Esse símbolo de transcendência e conhecimento parece pertencer somente aos homens de seu povoado: "Él nunca en su vida ha visto mujer con anteojos." (GALEANO, 1995, p. 10). Signos de conhecimento, esses objetos - óculos e livro - evocam outra característica frequentemente atribuída ao estereótipo da feiticeira: a sabedoria 
Religare, ISSN: 19826605, v.14, n.2, dezembro de 2017, p. 311-342.

ou detenção de um grande conhecimento ancestral e invulgar. Ao ser questionada pelo homem-réptil sobre o teor de sua leitura, ela objeta que se trata de lendas e esclarece que são antigas vozes que a acompanham, comunicandolhe assim uma sapiência primitiva da qual ele, evidentemente, está privado.

Verifica-se deste modo, na estrutura do conto, a existência de dois enredos que confluem, mas de um modo que difere das formas convencionais de histórias múltiplas dependentes de uma diegese principal, pois aqui, propõe-se uma trama já finalizada e prevista, que, no encontro entre Dulcidio e a mulher, culmina na sobreposição de duas histórias. Trata-se da história de Dulcidio e da história lida pela mulher na beira do rio, que estão, a partir de então, unidas e se articulam no mesmo enredo. Deste modo, essa mágica personagem demonstra saber não somente das verdades do tempo presente, ocultadas deliberadamente por Dulcidio, mas também conhecer o passado e antecipar o futuro. De fato, sua onisciência temporal nos remete às diversas representações femininas que personificam o destino na mitologia greco-romana. Moiras, Parcas, Ceres ${ }^{7}$, entre outras, configuram divindades femininas - mais ou menos abstratas, de acordo com o período histórico - que detém o poder e a responsabilidade sobre o destino humano, bem como o conhecimento acerca do passado, do presente e do porvir. Ademais, essa sapiência sobre-humana também pode ser encontrada nas Musas, divindades femininas que presidem as artes, como relatado por Hesíodo (1995) em sua Teogonia:

\footnotetext{
“Pastores agrestes, vis infâmias e ventres só, sabemos muitas mentiras dizer símeis aos fatos e sabemos, se queremos, dar a ouvir revelações". $[\ldots]$
}

\footnotetext{
${ }^{7}$ De acordo com Nuno Simões Rodrigues (2006, p. 248): “O passo, em que Zeus pesa na balança os fados dos dois heróis, ficou conhecido como «a pesagem dos Destinos». Aqui, «Destino»

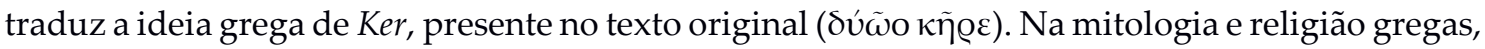
$\kappa \tilde{\eta} \varrho$ (Ker) é a deusa que personifica a Morte. É ela que, nas batalhas, leva cada herói, no momento da sua morte. Cer é representada como um ser alado, negro, com grandes e horrendos dentes brancos e unhas enormes e pontiagudas. Cer despedaça os cadáveres e bebe o seu sangue, assim como o dos feridos. Mas Cer é também conotada com o Destino, que domina a existência de todos os Homens, personificando a sua morte, para a qual converge, mas também o género de vida que lhe é atribuído. As Ceres podiam ser mais do que uma.".
} 
Religare, ISSN: 19826605, v.14, n.2, dezembro de 2017, p. 311-342.

Eia! pelas Musas comecemos, elas a Zeus pai hineando alegram o grande espírito no Olimpo dizendo o presente, o futuro e o passado vozes aliando. (v. 26-8/36-9).

Destarte, verifica-se que esse arquétipo da personagem feminina detentora de um saber divino, inacessível aos mortais - e ao homem, mais especificamente - pode ser identificado recorrentemente em matrizes mitológicas e culturais diversas. Essa grande sabedoria, frequentemente atribuída ao arquétipo feminino aqui analisado, ultrapassa o limite humano e não obedece ao modo de transmissão de conhecimento de formatação padronizada, erudita e tradicional remetendo, antes, à gnose ancestral, transmitida ritualisticamente e apenas aos iniciados em sua arte. No entanto, podemos observar que esse conhecimento, dentro da narrativa analisada, procede de um livro, objeto que representa a cultura tida como civilizada e canônica, em oposição ao conhecimento transmitido oralmente.

Portanto, podemos constatar que é reincidente na mitologia de variadas culturas a ideia da mulher mágica perversa detentora de um grande conhecimento. Responsável, na mitologia cristã, pelo desaparecimento do paraíso terrestre e acusada de ter introduzido o pecado, a desgraça e a morte na terra, a mulher teve como motivação, justamente, o desejo pelo discernimento divino. Convém pontuar, ainda, que esse conhecimento é geralmente adquirido por meios transgressores ou escusos:

A serpente disse então à mulher: "Não, não morrereis! Mas Deus sabe que, no dia em que dele comerdes, vossos olhos se abrirão e vós sereis como deuses, versados no bem e no mal". A mulher viu que a árvore era boa ao apetite e formosa à vista, e que essa árvore era desejável para adquirir discernimento. Tomou-lhe o fruto e comeu. (BÍBLIA, Gn, 13, 4-6)

Galeano propõe uma narrativa aparentemente fora da lógica dual e maniqueísta. Essa interpretação é possível graças ao fato de ambas as personagens centrais serem permeadas de elementos fantásticos e misteriosos e 
Religare, ISSN: 19826605, v.14, n.2, dezembro de 2017, p. 311-342.

de que, mesmo quando se opera a inversão final, esta se dá como uma revelação impactante e ambivalente entre as personagens, contudo sem nenhuma espécie de caráter punitivo explícito. Não obstante, outra leitura se mostra viável quando refletimos sobre a ampla dimensão de conhecimento de nossa heroína. Uma vez detentora de uma consciência que transcende os limites espaço-temporais, ela pode, tendo ciência de toda a violência infringida pelo homem-lagarto às mulheres - pobres vítimas de sua natureza voraz - manipular os sentimentos do malfeitor e dedicar-lhe a merecida vingança. Nessa interpretação, a mágica personagem simbolizaria a revanche de todas as nativas violentadas pelo agressor-colonizador.

A riqueza, por vezes ressaltada ao longo do conto e conferida ao aparente protagonista, contrasta rudemente com a pobreza da população local, da qual provém o mantimento exigido para sua constante fome: as mulheres que, como toda a população, fazem parte de suas posses. "Novias, no faltaban. En las casas pobres, siempre había alguna hija sobrando." (GALEANO, 1995, p. 10). A condição social do povo de Lucanamarca somada à desvalorização social de que padece o gênero feminino explica a sujeição das famílias ao glutão devorador de mulheres e detentor de todo o poder aqui descrito. A essa possibilidade interpretativa cabe acrescentar o fator da hibridez característica dos dois protagonistas da história. Ambos são humanos - e ambos não o são -, mas essa hibridez tem significações muito diferentes quando afetam homens e mulheres.

Como vimos, no esquema distintivo elaborado por Durand, a configuração híbrida de Dulcidio, participa mutuamente dos regimes noturno e diurno da imagem, agregando, em relação ao último, os valores negativos que cerceiam os répteis, ratos e pássaros noturnos, pertencentes à categoria dos símbolos teriomórficos. Nesse esquema encaixam-se também os casamentos nefastos entre seres sobrenaturais e os humanos. No entanto, em meio à névoa de mistério que envolve a personagem feminina, não verificamos ao longo do enredo, nenhum indício de um possível comportamento assassino ou de algum gesto perigoso. Ao contrário de Dulcidio, cuja natureza cruel é conhecida e aceita, 
Religare, ISSN: 19826605, v.14, n.2, dezembro de 2017, p. 311-342.

essa mulher parece ocultar sua verdadeira intenção, pois chega a tecer um falso e irônico elogio ao acariciar a couraça do presunçoso herdeiro: "Ella extiende la mano, acaricia la ferruginosa coraza y elogia: Es una seda." (GALEANO, 1995, p. 11), demonstrando assim sua sagaz personalidade.

O rico herdeiro, por sua vez, tem sua conduta animalesca justificada por sua natureza e essa é aceita com naturalidade pela comunidade local. Tal qual o canibalismo antropofágico descrito por Maria Cândida Ferreira de Almeida (2002), seus atos fazem parte de um ritual, uma cultura compartilhada por toda a sociedade. Em contraposição a Dulcidio, que ao devorar suas esposas não recebe nenhuma punição para tal ato, passando inclusive, a justificar sua postura como uma triste ironia do destino: "[...] y el muy saurio aclara que él es rico pero humilde, estudioso y trabajador, y ante todo un caballero con intenciones de formar un hogar, pero el destino cruel quiere que enviude" (GALEANO, 1995, p.11), a figura feminina, culta e sábia, dissimula sua natureza até o momento derradeiro da deglutição. Nesse momento, opera-se uma aparente inversão de papéis, em que a mulher passa a possuir as características até então atribuídas ao polo masculino da narrativa.

Para compreender essa diferenciação, podemos examinar, sucintamente, a construção da mulher ideal ao longo da Idade Média, paradigma que persiste até a modernidade e, em muitos redutos de pensamento, até o momento presente. Os padres da Igreja, apoiados no discurso da tradição greco-latina e, notadamente, na concepção neoplatônica, lançam discursos de exaltação mariana e reforçam o papel da igreja como regulamentadora das relações sexuais, por meio da imposição do matrimônio e da castidade feminina. Paralelamente à invenção desse ideal de mulher e com base, sobretudo, em Aristóteles, submetem as filhas de Eva ao escrutínio de uma misoginia ancestral. A literatura cortesã reforça, na ficção, essa mulher ideal, angelical, discreta e nobre, mas contesta o dogma cristão no que tange à sexualidade, propondo modelos que eram tabus sociais e pecados capitais em pleno século XII. A liberdade sexual, o gozo do corpo dos amantes ou a relação adúltera com damas desposadas eram fatos na 
Religare, ISSN: 19826605, v.14, n.2, dezembro de 2017, p. 311-342.

literatura dos trovadores que seriam severamente castigados fora das páginas da literatura. (GARCÍA GUAL, 1997).

No discurso religioso, como no discurso do senso comum, se expande uma misoginia escancarada que se difere desse ideal inalcançável de mulher (Mariadama) e, nesse sentido, a sociedade fortemente patriarcal apregoa que somente pela opressão e pela regulamentação do comportamento feminino poder-se-ia aplacar a dissimulada e perigosa ação da mulher, a fúria de sua ardileza, algo tão inerente à sua natureza quanto sua fraqueza espiritual, física e mental.

Ele só é seduzido pelas que lhe preparam armadilhas, oferecendo-se, ela é que vigia a presa; sua passividade está a serviço de um empreendimento, ela faz de sua fraqueza o instrumento de sua força; sendo-lhe proibido atacar francamente, fica adstrita às manobras e aos cálculos; e seu interesse consiste em parecer gratuitamente dada; por isso censuram-na por ser pérfida e traiçoeira: é verdade. Mas é verdade que é obrigada a oferecer ao homem o mito de sua submissão, por ele querer dominar. (BEAUVOIR, 1968, p. 96).

A sobrevivência desse modelo faz com que oito séculos mais tarde, a filósofa existencialista se depare novamente com essa suposta dissimulação, tão condenada nas mulheres, e conclua que ela seria o fruto produzido pelas exigências irreais às quais essas mulheres foram submetidas. Na tentativa vã de encarnar a entidade inumana do ideal masculino, ela estaria, involuntariamente ou não, sempre a traí-lo. Deste modo, a mulher permaneceria, inegavelmente, voltada à imoralidade, uma vez que a moralidade imposta pela sociedade patriarcal é constituída por um referencial propositalmente impossível de ser atingido.

Destarte, na obra de Galeano, mesmo no momento em que ocorre a inversão e a protagonista realiza o macabro banquete, ela parece pressentir que não gozará da mesma tolerância que o homem quando decide sanar livremente seus "apetites". Para apaziguar esse fato e não tornar-se alvo de censura ou constrangimento, a ação inclui a dissimulação. Vemos, assim, no parágrafo final do conto, uma preocupação da mulher para não acordar o amante enquanto o 
Religare, ISSN: 19826605, v.14, n.2, dezembro de 2017, p. 311-342.

mastiga, o que está em conformidade com o cuidado e a suavidade que são atribuídos comumente ao sexo feminino: "Ella se lo come dormido. Lo va tragando de a poquito, desde la cola hasta la cabeza, sin hacer ruido ni mascar fuerte, cuidadosa de no despertarlo, para que él no vaya a llevarse una fea impresión". (GALEANO, 1995, p. $14)$.

Observamos aqui uma clara distinção entre as ferozes devorações de Dulcidio e a descrição do engolimento intimista dessa personagem pela mulher. Até mesmo o simbolismo expresso nos vocábulos elegidos pelo autor denota essa diferenciação: Dulcidio "se lança sobre" e "devora" suas noivas - ação animalesca vinculada ao regime diurno da imagem. Por outro lado, ela "se lo come" (cujo uso reflexivo do verbo atenua ainda mais a ação), "traga", " ni mascar fuerte" - conjunto de ações que "contribui, sobretudo, para reforçar as qualidades eufêmicas do engolimento", relacionadas ao regime noturno da imagem. É dessa forma que "o engolimento se distingue do morder negativo". (DURAND, 1997, p. 216). Assim:

(...) é assim a boca que passa a simbolizar toda animalidade, que se torna o arquétipo devorador (...). Reparemos bem num aspecto essencial deste simbolismo: trata-se exclusivamente da boca armada com dentes acerados, pronta a triturar e a morder, e não da simples boca que engole e que chupa que - como veremos - é a exata inversão do presente arquétipo. (DURAND, 1997, p. 84)

Além disso, a mastigação lenta que caracteriza o ato de devorar realizado pela personagem mágica configura, de acordo com o pensamento do mitólogo, a negação agressiva do alimento (vítima) em vista não propriamente de uma destruição, mas de uma transubstanciação que justifica esse ato. A operação alquímica aqui realizada sublinha que os complexos de mutilações estão ligados nessa obra galeana ao tema da aniquilação, como nos ataques das bacantes em êxtase que, na mitologia clássica, realizavam o desmembramento antes da devoração.

Frye, em sua teoria do sentido arquetípico na literatura, descreve esse tipo de ato canibal efetuado pelo viés das imagens demoníacas: 
Religare, ISSN: 19826605, v.14, n.2, dezembro de 2017, p. 311-342.

As imagens do canibalismo habitualmente incluem não apenas imagens de tortura e mutilação, mas também do que tecnicamente se conhece como sparagmós, ou despedaçamento do corpo sacrifical, imagem essa que se encontra nos mitos de Osíris, Orfeu e Penteu. (NORTHROP, 1973, p. 150)

Essa conformidade com a manutenção de uma imagem social que é exigida da figura feminina também se reflete no comportamento anterior dessa personagem. Ao contrário da sedutora eloquência típica das personagens que encarnam a arquétipo do feminino maléfico na literatura, a mística mulher engana com seu silêncio, qualidade tão apreciada no sexo feminino. A doce voz elogiosa e salteada de silêncios remete à submissão, delicadeza e obediência, características igualmente apreciadas na mulher. Nem a personagem nem o leitor esperam que tamanha brandura possa abrigar a deusa morte.

Marina Warner (1999), em sua análise da linguagem feminina nos contos de fadas, considera que a dona de casa exemplar segundo os impressos da Reforma, a que usa um cadeado nos lábios, ainda permeia os contos como a heroína modelar. A autora exemplifica na figura de Cordélia, personagem shakespeariana, o silêncio como prova de virtude. A falta de palavras da personagem gera a verdade, a mudez sacrificial que vem como um sinal de renúncia e abnegação, pois as mentiras seriam mascaradas através de belas e falsas palavras. Na tragédia de Shakespeare, Rei Lear, o pai de Cordélia declara: "Sua voz sempre foi suave, gentil e baixa, grande virtude em uma mulher". (WARNER, 1999, p.430). Warner acrescenta ainda:

Ruth Bottigheimer, num estudo sobre os contos dos irmãos Grimm, Bad girls and bold boys (meninas más e meninos audazes), analisou o discurso de heroínas e vilãs e descobriu que, no processo de edição, as virtuosas calavam cada vez mais e as vilãs tornavam-se cada vez mais loquazes - bruxas e madrastas malvadas eram, de longe, mais articuladas do que outras personagens do sexo feminino. A equação do silêncio com a virtude, da paciência com a feminilidade, não se limitava a apresentar um ideal encantador de auto abnegação, de harmonia e de sabedoria; segundo os contos de faz de conta transmitidos 
Religare, ISSN: 19826605, v.14, n.2, dezembro de 2017, p. 311-342.

para as crianças, o ideal também satisfazia certos requisitos socioculturais de equilíbrio familiar na atmosfera da Alemanha do início do século XIX, e que continuam sendo desejáveis. (1999, p.434)

O que Marina Warner denomina "o paradoxo da linguagem" é a noção de que, na ausência de palavras, cresceria a sinceridade, ação que se opõe à fraudulência da fala eloquente, insubstancial, como o ar que, para Hamlet, soa como o tecido falso apresentado para iludir. Entretanto, esse silêncio mantém implícita uma pregação moral sobre o amor e o dever, o auto- sacrifício e a expiação feminina. A autora destaca também que a utilização do silêncio pode ter sido durante séculos uma estratégia de sobrevivência para os humildes e impotentes e, portanto, para as mulheres. Segundo Warner ainda:

Mas esse mutismo pode também coincidir com o desejo dos poderosos; o caráter desejável do silêncio, ou pelo menos da reticência, e do silencio feminino em particular, compõe uma rede de outros critérios ideais impostos ao sexo feminino. Como discutimos anteriormente. É até possível que mais uma razão oculta para o desaparecimento das mães nos contos de fadas seja que a perfeição feminina implica silêncio e auto anulação - a ponto de efetivamente elas sumirem do texto.

(1999, p. 436).

Assim a postura reticente da personagem feminina de Galeano, que mesmo ciente das mentiras por ele pronunciadas e de suas reais intenções parece omitir-se de modo subserviente, aparenta, inicialmente, ser a reprodução, nada incomum, do papel da mulher na literatura. Inclusive, esse pode ter sido o recurso utilizado para sua sobrevivência pelos tempos, passando despercebida por aqueles que invadiram suas terras, o recurso do nativo que sobrevive à violenta colonização e à imposição cultural. A mudez, assim como o não retrucar, poderia, ainda, marcar sua condição estrangulada e diminuída. Porém, seu silêncio se revela, na trama astuciosa, uma ocultação de sua verdadeira essência, ao passo que também fomenta o mistério, outro artifício que caracteriza a encarnação da feiticeira e que atua como chamariz para atrair suas vítimas. 
Religare, ISSN: 19826605, v.14, n.2, dezembro de 2017, p. 311-342.

No que tange à temática, no conto ecoa a repetição, já conhecida, do príncipe que mata suas esposas sucessivamente após as núpcias, tal qual ocorre em As mil e uma noites ou na obra de John Barth, Dunyazadíada, de 1986. Em um momento histórico no qual os movimentos feministas já haviam introduzido profundas mudanças na estrutura social e cultural no ocidente, a abordagem realizada por Eduardo Galeano não permanece alheia a essa questão. No entanto, no intuito de desconstrução do arquétipo do masculino devorador, Galeano termina por reproduzir outro mito misógino. Assim, insere-se mais uma vez na narrativa, a temática chamada por Durand (1997) de "a mulher fatal", que consiste em nada mais que a reprodução desse arquétipo da feminilidade mortífera, delineado pela realização de uma sexualidade feminina perigosa. Trata-se novamente, da mulher misteriosa e encantadora que desperta interesse e provoca paixões para conduzir seus amantes à perdição e, por vezes, à morte, através de sua sexualidade.

Alguns elementos simbólicos analisados por Durand (1997) em sua obra como pertencentes ao universo mítico do nosso imaginário, aos símbolos nictomórficos do Regime Diurno da imagem, evidenciam-se como qualificadores dessa feminilidade fatal, sendo o principal deles, mais uma vez, a água. O elemento misterioso e hostil apresenta-se no conto "Historia del lagarto que tenía la costumbre de cenar a sus mujeres" na composição do espaço explicitamente vinculado à personagem feminina: o rio. Assim, de acordo com Durand (1997, p. 96), “A água que escorre é amargo convite à viagem sem retorno: nunca nos banhamos duas vezes no mesmo rio e os cursos de água não voltam à nascente. A água que corre é figura do irrevogável”.

Para Durand (1997), a água, mesmo em seus diferentes aspectos, é um elemento ligado ao feminino, pertencendo ambos ao mesmo esquema arquetípico. Quando interligados, eles apresentam características mortuárias, tornando-se a duplicação substancial das trevas (1997). No conto de Galeano, a água se conecta ao feminino pela presença da personagem ribeirinha aqui analisada. Destarte, valendo-nos de uma perspectiva mitocrítica simbólica e 
Religare, ISSN: 19826605, v.14, n.2, dezembro de 2017, p. 311-342.

levando em consideração a vinculação das personagens femininas perversas ao elemento aquático, podemos analisar essas manifestações figurativas como adjacentes ao mito da sereia e diretamente conectadas à questão da configuração arquetípica do poder nefasto do Feminino, mais especificamente, da Grande Mãe em seu aspecto elementar negativo, preponderante na narrativa ora analisada.

Diretamente vinculada à configuração do arquétipo feminino, a água, componente recorrente nas narrativas literárias, destaca-se como elemento rico em simbologia, ampla e tradicionalmente relacionado ao feminino e, portanto, capital para a construção dessas personagens. Assim, cabe aos estudos analíticos do mito investigar a motivação para a presença constante da associação águamulher na mitologia e suas possíveis significações, tanto no folclore quanto na literatura. É amplo o número de entidades femininas conhecidas nas narrativas orais ou escritas relacionadas à água: deusas, ondinas, sereias, mães d'água, melusinas, ninfas e tantas outras são entidades de signo marcadamente feminino que vivem em lagoas, mares, fontes ou rios. Feiticeiras sedutoras como Mélusine, elas têm múltiplas antecessoras, não só na mitologia clássica (na Odisseia, Calipso e Circe) mas também no folclore celta na figura dos Selkies (gênios das águas).

Como já mencionado, a aproximação entre a água e a feminilidade não é nova e já foi analisada por vários estudiosos do mito como Gilbert Durand (1997) ou Gaston Bachelard (1998). O primeiro, em sua obra As Estruturas Antropológicas do Imaginário, classifica esse elemento natural como pertencente ao que nomeia variação nictomórfica. Tendo sido o primeiro espelho, dormente e sombrio, do homem, Durand o caracteriza como símbolo da feminilidade noturna e terrível:

A Grande Mãe é seguramente a entidade religiosa e psicológica mais universal. Aditi é a origem e a soma de todos os deuses que estão nela: Astarte, Ísis, Dea Syria, Mâyâ, Marica, Magna Mater, Anaitis, Afrodite, Cibele, Réia, Géia, Deméter, Míriam, Chalchiuhtlicue ou Shing-Moo são os seus nomes inumeráveis que nos remetem para atributos telúricos ou para epítetos aquáticos, mas que são sempre, em todos os casos, símbolos de um terror ou de uma nostalgia. (DURAND, 1997, p. 234). 
Religare, ISSN: 19826605, v.14, n.2, dezembro de 2017, p. 311-342.

Para Durand, a água associa-se ao feminino pelo aspecto menstrual, que vem ainda determinar a valorização temporal. Dessa forma, o sangue, considerado por ele o primeiro relógio humano correlativamente associado ao drama lunar, afirma a temporalidade e implementa a angústia humana perante a ciência da efemeridade de sua existência, advertindo o homem, então, acerca do poder fulminante do tempo. Assim, o autor afirma que:

E ainda:

Os símbolos nictomórficos são, portanto, animados em profundidade pelo esquema heraclitiano da água que corre ou de cuja profundidade, pelo seu negrume, nos escapa, e pelo reflexo que redobra a imagem como a sombra redobra o corpo. Esta água negra é sempre, no fim das contas, o sangue, o mistério do sangue que corre nas veias ou se escapa com a vida pela ferida, cujo aspecto menstrual vem ainda sobredeterminar a valorização temporal.

O que constitui a irremediável feminilidade da água é que a liquidez é o próprio elemento dos fluxos menstruais. Pode-se dizer que o arquétipo do elemento aquático e nefasto é o sangue menstrual. É o que é confirmado pela ligação frequente, embora insólita à primeira vista, da água e da lua. (DURAND, 1997, p. 101).

Assim sendo, a sujeição das águas (sejam elas marinhas, fluviais ou menstruais) ao fluxo lunar, é, para o autor, o isomorfismo constante que liga o feminino a esse elemento. Para o estudioso do imaginário, a lua está indissoluvelmente ligada à feminilidade, e é pela feminilidade que adentramos no simbolismo aquático. Todos esses seriam, pois, elementos que propiciariam a agonia humana diante dos indícios irrefutáveis da forçosa sujeição do homem à inexorável passagem do tempo.

E quando a morte e o tempo forem recusados ou combatidos em nome de um desejo polêmico de eternidade, a carne sob todas as suas formas, especialmente a carne menstrual que a feminilidade é, será temida e reprovada como aliada secreta da temporalidade e da morte. (Id. Ibid., p. 121).

No imaginário, água e feminilidade compartilhariam de atributos como a 
Religare, ISSN: 19826605, v.14, n.2, dezembro de 2017, p. 311-342.

fluidez, a fecundidade, a sensualidade e a instabilidade. Todavia, a relação entre o feminino e as águas se estabelece por muitas outras vias de conexão. Alguns autores consideram a umidade do sexo feminino pela excitação ou pelo estado menstrual sua ligação nata com o elemento aquático. Outros vinculam a sensação intrauterina de conforto e proteção com o mergulho completo do corpo nas águas ou, ainda, a produção do leite materno como alimento básico primário e fonte de vida, que é essencialmente análogo à água, quer dizer, líquido e dom inesgotável e gratuito da mãe natureza.

Para o homem, a maternidade permanecerá provavelmente sempre um mistério profundo e Karen Horney sugeriu com verossimilhança que o medo que a mulher inspira ao outro sexo prende-se especialmente a esse mistério, fonte de tantos tabus, de terrores e de ritos, que a religa, muito mais estreitamente que seu companheiro, à grande obra da natureza e faz dela o santuário do estranho. (DELUMEAU, 1993, p. 311).

Assim, os simbolismos que envolvem esse elemento, água, e a feminilidade, mulher, podem apresentar polos distintos, sendo um deles maternal e acolhedor (vinculado ao desejo de ser envolvido completamente na substância morna, suave e protetora e à necessidade de uma matéria que circundaria o ser por inteiro e o penetraria intimamente), remetendo assim ao conforto uterino; e outro polo, sensual e terrível, sendo o que constitui evidentemente o aspecto predominante no conto aqui analisado. Para Jean Delumeau (1993), é do jogo dualizado entre esses dois aspectos opositivos atribuídos à mulher que se desencadeia no imaginário o terror perante o feminino:

Essa ambiguidade fundamental da mulher que dá a vida e anuncia a morte foi sentida ao longo dos séculos, e especialmente expressa pelo culto das deusas-mães. A terra mãe é o ventre nutridor, mas também o reino dos mortos sob o solo ou na água profunda. É o cálice de vida e de morte. É como essas urnas cretenses que continham água, o vinho e o cereal e também as cinzas dos defuntos. (DELUMEAU, 1993, p. 312.).

Em sua obra História do medo no Ocidente (1993), Delumeau recupera, em uma perspectiva diacrônica, as origens históricas e antropológicas do medo na 
Religare, ISSN: 19826605, v.14, n.2, dezembro de 2017, p. 311-342.

civilização ocidental, fornecendo-nos um fecundo panorama do desenvolvimento dessa faceta humana através do tempo. Anteriormente, Simone de Beauvoir, em ambos os volumes de sua obra $O$ segundo Sexo, publicada em 1949, já havia descrito essa relação entre mistério e feminino - que, permeando o imaginário coletivo, culminaria no temor ao "segundo sexo" -, bem como fundamentado sua origem na ambivalência controversa de nascimento e morte, vinculando-o, ainda, aos temores da natureza:

Tem, assim, a Mulher-Mãe um rosto de trevas: ela é o caos de que tudo saiu e ao qual tudo deve voltar um dia; ela é o Nada. Dentro da Noite confundem-se os múltiplos aspectos do mundo que o dia revela: noite do espírito encerrado na generalidade e na opacidade da matéria, noite do sono e do nada. No fundo do mar impera a noite: a mulher é o Mare tenebrarum temido dos antigos navegadores; a noite impera nas entranhas da terra. Essa noite pela qual o homem receia ser tragado, e que é o inverso da fecundidade, apavora-o. Ele aspira ao céu, à luz, aos picos ensolarados, ao frio puro e cristalino do azul; e, a seus pés, há um abismo úmido e quente, obscuro, pronto para abocanhá-lo; numerosas lendas mostram-nos o herói que se perde para sempre recaindo nas trevas maternas: caverna, abismo, inferno. (BEAUVOIR, 1970, p. 185).

A autora ainda acrescenta:

[...] o sexo feminino é misterioso até para a própria mulher, é escondido, atormentado, mucoso, úmido, sangra todos os meses e é, por vezes, maculado de humores, tem uma vida secreta e perigosa. É em grande parte porque a mulher não se reconhece nele que não reconhece seus os desejos dele. (BEAUVOIR, 1968, p.124).

Desse aspecto dúbio, imputado ao caráter feminino, advém, para Delumeau (1993), a existência das inúmeras deusas vinculadas à morte assim como as representações de monstros associados à mulher nas lendas de diversas civilizações, sendo Kali, a deusa hindu, mãe do mundo, o maior exemplo que os homens teriam forjado da mulher ao mesmo tempo criadora e destruidora. $\mathrm{O}$ historiador considera que o motivo para o temor masculino da mulher ultrapassa o conceito freudiano do medo da castração, contudo admite que esse receio 
Religare, ISSN: 19826605, v.14, n.2, dezembro de 2017, p. 311-342.

encontra-se manifesto nas diversas versões do mito da vagina dentada que ressoa, com algumas variações, na mitologia indígena de diferentes regiões da América e também entre povos da Europa. Nesse mito, reforça-se e se manifesta o temor do homem perante o suposto canibalismo sexual da sua parceira.

Além disso, a demonização do feminino não é novidade no meio filosófico e científico, haja vista a constatação de uma produção literária frequentemente hostil à mulher. É sabido que a cultura erudita ocidental, durante muito tempo, manteve atrelado o discurso oficial das autoridades eclesiásticas à essência de suas verdades, sobretudo a perspectiva ontológica e a moral cristãs, nas quais o feminino é habitualmente vilipendiado.

Mal magnífico, prazer funesto, venenosa e enganadora, a mulher foi acusada pelo outro sexo de ter introduzido na terra o pecado, a desgraça e a morte. Pandora grega ou Eva judaica, ela cometeu a falta original ao abrir a urna que continha todos os males ou ao comer o fruto proibido. O homem procurou um responsável para o sofrimento, para o malogro, para o desaparecimento do paraíso terrestre, e encontrou a mulher. Como não temer um ser que nunca é tão perigoso como quando sorri? A caverna sexual tornou-se a fossa viscosa do inferno. (DELUMEAU, 1993, p. 314).

No discurso religioso, a mulher é tida, nesse sentido, como ser predestinado ao mal e à perversidade que, amalgamados à sua essência, lhe são inerentes. Desse modo, ela está sujeita a ser dominada pelo potencial perigoso que é atribuído à sua impureza fundamental e orgânica e à sua força misteriosa. Esses são conceitos que se consolidam em uma iconografia malévola tradicionalmente consagrada ao feminino.

O homem procura na mulher o outro como Natureza e como seu semelhante. Mas conhecemos os sentimentos ambivalentes que a Natureza inspira ao homem. Êle a explora, mas ela o esmaga, êle nasce e morre nela; é a fonte de seu ser e o reino que êle submete à sua vontade; uma ganga material em que a alma se encontra presa, e é a realidade suprema; é a contingência e a ideia, a finalidade e a totalidade; é o que se opõe ao Espírito e o próprio espírito. Ora aliada, ora inimiga, se apresenta como o caos tenebroso de que surge a vida, como essa vida, e como o além para o qual tende: a mulher resume a Natureza como Mãe, 
Religare, ISSN: 19826605, v.14, n.2, dezembro de 2017, p. 311-342.

Esposa, e Ideia. Essas figuras ora se confundem e ora se opõem, e cada uma delas tem dupla face. (BEAUVOIR, 1970, p. 182).

É esse o aspecto do arquétipo do feminino perigoso que aflora na obra de Galeano (1993). Nela, a dimensão mítica é ainda potencializada pela presença do mitema ${ }^{8}$ aquático que, assim como o feminino, suscita o medo provindo do mistério e representa, na história do desenvolvimento do medo na humanidade, um dos temores primários, formador de uma série de esquemas arquetípicos no imaginário e na mitologia. $\mathrm{O}$ mitema aquático pode retomar o medo ancestral das águas misteriosas, cuja profundidade é desconhecida por seu negrume e seu sempiterno e, portanto, temível mistério. Além disso, encontra-se presente também no temor do poder de destruição das águas, ideia retomada pela recorrente iconografia do dilúvio (mito praticamente universal) e do naufrágio em diferentes civilizações, que adquire, na literatura moderna e contemporânea, uma presença poética bastante significativa. As analogias entre água, sexualidade e feminilidade e entre vida e morte parecem ser coeficientes comuns nesses trabalhos. Os aspectos benéficos, mas também destrutivos e agressivos das águas, convivem em um mesmo espaço e tempo. Desse modo, afirma Durand (1997, p. 96): “O homem que não pode viver sem a água não deixa de sofrer com ela: as inundações tão nefastas, ainda são acidentais, mas o lodaçal e o pântano são permanentes e vão crescendo".

Na construção mítica, a aproximação entre mulher e água se projeta em inúmeras representações de recortes da natureza, conexões que se estabelecem cultural e socialmente e que podem ser averiguadas na literatura também. Dessa forma, o medo da água teria uma origem ancestral indeterminada, vindo do tempo em que os homens primitivos consideravam as águas profundas como o abismo devorador, sempre pronto a lhes engolir vivos. Esse temor se estenderia assim ao feminino, ao minimizar-se no medo venial da vagina e do coito e nos mistérios da fecundação e da maternidade. Para Durand (1997), como vimos, é

\footnotetext{
${ }_{8}^{8}$ Nomenclatura empregada pelos estudiosos do mito segundo a perspectiva antropológicoestruturalista, o mitema constitui a partícula mais essencial de um mito, sua unidade mínima.
} 
Religare, ISSN: 19826605, v.14, n.2, dezembro de 2017, p. 311-342.

na assimilação do tempo e da morte lunar das menstruações e dos perigos da sexualidade que é introduzida a misoginia na imaginação. Se tal é o medo de que padece o homem perante o universo do desconhecido que lhe parece ser a mulher, mais poderosas ainda serão as feiticeiras, as ninfas, as bruxas, as sereias, as ondinas que escapam completamente a seu domínio. São esses os seres mágicos que, encarnados nas obras literárias de diversos momentos históricos, despertam o terror.

Outro elemento encontrado na obra que também estabelece um vínculo com o mitema da água é a cabeleira: "Ella echa a bailar su larga trenza de pelo negro, como quien oye llover..." (GALEANO, 1995, p. 11). Assim como a água, esse componente também corrobora a significação de mistério que suscitaria o temor, conectando-se à ideia de morte:

Uma outra imagem frequente e muito mais importante na constelação da água negra é a cabeleira. Ela vai imperceptivelmente fazer desligar os símbolos negativos que estudamos para uma feminização larvar, feminização que será definitivamente reforçada por essa água feminina e nefasta por excelência: o sangue menstrual. (DURAND, 1997, p. 99).

Constatamos, desse modo, como estruturas sociais representadas na obra literária, de fato, relacionam-se a elementos míticos, perpetuando e reforçando, assim, os arquétipos presentes no inconsciente coletivo, bem como o modo pelo qual esses mesmos paradigmas figurativos - como a imagem da bruxa sintetizadora do feminino maléfico e mágico - ecoam historicamente nas obras literárias e podem, ainda, ser encontrados inclusive em uma literatura contemporânea que, almejando ideologicamente sua contestação, inadvertidamente os reproduz. 
Religare, ISSN: 19826605, v.14, n.2, dezembro de 2017, p. 311-342.

\section{Considerações finais}

Como pudemos analisar, o conto "Historia del lagarto que tenía la costumbre de cenar a sus mujeres" (1993), de Eduardo Galeano, constitui uma fértil amostra do imaginário humano no que tange à reflexão acerca das representações maléficas do feminino no universo mítico-literário.

Na narrativa, converte-se o devorador no deglutido, em uma espécie de, à primeira vista, acerto de contas entre opressor e oprimida(s). Para que se alcance tal clímax, entretanto, há de se acompanhar o paradigmático processo de sedução sirênica por meio do qual nossa mulher-feiticeira o enreda em seu ardil. Nesse embate, há, notoriamente, uma dicotomia que se perfaz na relação entre nativo/natureza - mulher - e colonizador/civilização - Dulcidio.

Tal oposição, porém, à luz da teoria do imaginário de Gilbert Durand (1997), se revela muito além de uma estruturação pautada por um formalismo redutor; constitui, antes, uma conjuntura dinâmica, dialógica e variegada, em que as diferentes imagens que compõem a conjuntura da narrativa e dos personagens transitam, dialeticamente, entre os regimes diurno e noturno e seus variados símbolos.

Destarte, a própria configuração híbrida de ambas as personagens não se submete a uma vulgar análise binária, sua categorização não é estanque e tampouco esgota a riqueza do simbolismo do conto. Não obstante, uma aproximação relativa da caracterização de Dulcidio ao regime diurno da imagem e da mulher ao noturno pode ser profícua: a conquista e dominação daquele são, por fim, tragadas, digeridas e absorvidas neste último.

Embora seja evidente que o conto propõe-se, axiologicamente, à defesa do feminino, ele não escapa à reprodução do imaginário misógino consubstanciado no mito da mulher fatal associada às águas, da feiticeira-sereia que detém os mistérios do tempo, os mistérios do amor, os mistérios da morte. 
Religare, ISSN: 19826605, v.14, n.2, dezembro de 2017, p. 311-342.

\section{Referências}

ALMEIDA, Maria Cândida Ferreira de. Tornar-se o outro - os Topos Canibal na literatura brasileira. São Paulo: Annablume, 2002.

BACHELARD, Gaston. A água e os sonhos. Trad. Antonio de Pádua Danesi. São Paulo: Martins Fontes, 1998.

BARTHES, Roland. Mitologias. Trad. Rita. Buongermino e Pedro de Souza. Rio de Janeiro: DIFEL, 2003.

BEAUVOIR, Simone de. O segundo sexo II: a experiência vivida. Trad. Sérgio

Milliet. 2. ed. São Paulo: Difusão Européia do Livro, 1967.

BRUNEL. Pierre. Dicionário de mitos literários. $3^{\underline{a}}$ Ed.Trad. de Carlos Sussekind e outros. Rio de Janeiro: J. Olympio, 2000.

CALASSO, Roberto. A literatura e os deuses. Trad. Jônatas Batista Neto. São Paulo:

Companhia das Letras, 2004.

CASSIRER, Ernst. Linguagem e mito. $4^{\mathrm{a}}$ ed. Trad. da editora (s/c). São Paulo:

Perspectiva, 2000.

DELUMEAU, Jean. História do medo no Ocidente. São Paulo. Companhia das

Letras, 2009

DUBY, Georges; PERROT, Michelle (orgs.). Historia de las mujeres. 5. ed. Madrid: Santillana, 2006. $5 \mathrm{v}$.

DURAND, Gilberto. As estruturas antropológicas do imaginário. São Paulo:

Martins Fontes, 1997.

DURAND, Gilbert. A imaginação simbólica. Trad. da $6^{\mathrm{a}}$ ed. francesa por Carlos A. de Brito. Lisboa: Edições 70, 1995.

ELIADE, Mircea. O mito do eterno retorno. Trad. Mauela Torres. Lisboa: Edições 70, 1985.

Fontes, 2001.

. O sagrado e o profano. Trad. Rogério Fernades. São Paulo: Martins

FERNANDES, Luiz Carlos. O fantástico e o maravilhoso da solidão latino-americana. Itinerários. Araraquara, 2002 p. 55.

FOUCAULT, Michel. História da sexualidade: a vontade de saber. 11. ed. Trad.

Maria Thereza da Costa Albuquerque; J. A. Guilhon Albuquerque. Rio de janeiro:

Graal, 1993.

FRIEDAN, Betty. Mística feminina. Trad. Áurea B. Weissenberg. Petrópolis: Vozes, 1971.

FRYE, Northrop. Fábulas de identidade. Trad. Sandra Vasconcelos. São Paulo: Nova Alexandria, 2000.

FURTADO, Filipe. A Construção do Fantástico. Lisboa: Livros Horizonte, 1980.

GALEANO, Eduardo H. Mujeres. Madrid: Alianza Editorial, 1995.

L\&PM, 201

As veias abertas da América Latina. Trad. Sergio Faraco. Porto Alegre:

GARCÍA GUAL, Carlos. El redescubrimiento de la sensibilidad en el siglo XII: el amor cortés y el ciclo artúrico. Madrid: Ediciones Akal, S. A., 1997. 
GRIMAL, Pierre. Dicionário da Mitologia grega e romana. $2^{\underline{a}}$ ed. Trad. Victor Jabouille. Lisboa/Rio de Janeiro: DIFEL/Editora Bertrand Brasil, 1993.

HARVEY, Paul. Dicionário Oxford de literatura clássica grega e latina. Trad. Mário da Gama Kury. Rio de Janeiro: Zahar, 1987.

HESÍODO. Teogonia: A Origem dos Deuses. Estudo e tradução de J. A. A. Torrano. São Paulo: Iluminuras, 1995.

LÉVI- STRAUSS, Claude. Antropologia estrutural. Trad. Chaim Samuel Katz, Eginardo Pires; revisão etnológica de Júlio Cezar Melatti - Rio de Janeiro: Tempo Brasileiro, 1996.

MARCO, Joaquim. Literatura Hispanoamericana: del modernismo a nuestros dias. Madrid: Filología, 1987.

JIMÉNEZ, Rafael. M. Mérida. La fantasía imposible: apuntes metodológicos para el Medioevo castellano. In: Brujas, demonios y fantasmas en la literatura

fantástica hispánica, Jaume Pont (ed.), Lleida: Universitat de Lleida, 1999, pp. 43-53. MORANT, Isabel (dir.). Historia de las mujeres en España y América Latina. 4 vols. Madrid: Cátedra, 2006.

NEUMANN, Erich. (1996). A Grande Mãe. Tradução de Fernanda Pedroza de Mattos e Maria Silia Mourão Netto. São Paulo: Cultrix, 1996.

NORTHROP, Frye. Anatomia da crítica. Trad. Péricles Eugenio da Silva Ramos. São Paulo: Cultrix, 1973.

PIZARRO, Ana. (Org). America Latina - Palavra, Literatura e Cultura: Vanguarda e Modernidade. Volume 3. Campinas: Editora UNICAMP, 1995 PRAZ, Mario. A carne, a morte e o diabo na literatura romântica. Trad. Philadelpho Menezes. Campinas: Editora da Unicamp, 1996.

PROPP, Vladimir. As raízes históricas do conto maravilhoso. Trad. Rosemary Costhek Abílio e Paulo Bezerra. São Paulo: Martins Fontes, 1997.

RODRIGUES, Nuno Simões. Um tema egípcio na Ilíada: a Kerostasia. In: Estudos em homenagem ao Professor Doutor José Amadeu Coelho Dias. Vol. 2, p. 247-258, 2006.

TODOROV, Tzvetan. Introducción a la literatura fantástica. Chile: Editorial. Tiempo Contemporâneo, 1970.

VOLOBUEF, Karin (Org.) Dimensões do fantástico, mítico e maravilhoso.

Araraquara: Cultura Acadêmica, 2011.p.37-46.

WARNER, Marina. Da fera à loira. Trad. Thelma Médici Nóbrega. São Paulo: Companhia das Letras, 1999. 